\title{
RELATÓRIO DE ESTÁGIO
}

\section{ARTIGO ORIGINAL}

MENEGHETTI, Francielli Jaqueline de Paula ${ }^{1}$

MENEGHETTI, Francielli Jaqueline de Paula. Relatório de estágio. Revista Científica Multidisciplinar Núcleo do Conhecimento. Ano 05, Ed. 10, Vol. 12, pp. 2349. Outubro de 2020. ISSN: 2448-0959, Link de acesso: https://www.nucleodoconhecimento.com.br/educacao/estagio,

DOI: 10.32749/nucleodoconhecimento.com.br/educacao/relatorio-de-estagio

\section{RESUMO}

Este trabalho trata-se da adaptação de um dos relatórios de estágios realizados durante a formação em Pedagogia na Faculdade de Sorriso-MT. O objetivo desta publicação é demonstrar como a prática do estágio é essencial à vida do estudante, especialmente para desenvolvimento prático da docência. Embora essa produção trate apenas de um dos estágios desenvolvidos na Educação Infantil, os estágios compuseram desde o Ensino Infantil, passando pelo Ensino de Jovens e Adultos até o de práticas de gestão escolar.

Palavras-chave: relatório de estágio, teoria.

\section{INTRODUÇÃO}

O acadêmico licenciado em Pedagogia executa várias funções durante o período de formação. O trabalho aqui realizado busca discutir a prática de estágio que ocorreu durante o curso de formação. Realizado em várias etapas, o estágio visa ao aperfeiçoamento profissional e pessoal para uma formação sólida e consistente.

\footnotetext{
${ }^{1}$ Especialização em Psicopedagogia e Distúrbios da aprendizagem. Graduação em Pedagogia.

RC: 61320

Disponível em: https://www.nucleodoconhecimento.com.br/educacao/estagio
} 
No estágio da Educação Infantil, o conhecimento era mediado de forma lúdica para que os alunos do maternal II aprendessem brincando. Nas séries iniciais, foram aproveitados alguns jogos em sala, mas os conteúdos eram dos livros fornecidos pela prefeitura para as crianças e, com isso, os alunos tinham subsídios para a aprendizagem.

\section{APONTAMENTOS TEÓRICOS: A EDUCAÇÃO INFANTIL}

O tratamento com a criança, na Idade Média, pautava-se em costumes e visões oriundas da Antiguidade. O papel da criança tinha forte definição pelo pai, cujos direitos tanto contemplavam o controle de filho, que era passível, em caso de rejeição, de ser morto.

Segundo Crepaldi (2017), a família é o primeiro ambiente no qual o indivíduo inicia sua vida em sociedade. Além disso, no seio familiar, a criança começa a desenvolver diversas áreas da vida, cabendo à família o contato e a transmissão de normas, ética, valores e crenças sociais para que a criança viva em sociedade.

Para discutirmos os processos pelos quais a criança passa, trazemos a visão de Piajet. Conforme Abreu et al. (2010), a teoria do autor suíço compreende quatro estágios de desenvolvimento infantil. No primeiro, que vai do nascimento aos dois anos de vida, a criança atinge um nível biológico e cognitivo (ABREU et al., 2010). O segundo, por sua vez, pré-operatório, "[...] calcado na constituição anda incipiente de uma estrutura operatória, e permanece nele até completar mais ou menos 7-8 anos, sendo que o desequilíbrio próprio é atingido aqui quando a criança está com a idade de 4-5 anos." (ABREU et al., 2010, p.363). O terceiro, por sua vez, operatório concreto, se volta à "[...] capacidade de coordenar ações bem ordenadas em 'sistemas de conjunto ou 'estruturas' [...]” (Ibid., p.363). O quarto e último, operatório formal, é aquele em que o sujeito permanece pela vida adulta e atinge equilíbrio próprio por volta dos 14 anos (Ibid., p.363).

RC: 61320

Disponível em: https://www.nucleodoconhecimento.com.br/educacao/estagio 
Sabemos que a educação tem o objetivo de assegurar a formação e o desenvolvimento físico, intelectual e moral do ser humano. Pensando nisso, é preciso que tanto a família quanto a escola andem sempre juntas. Segundo Santos e Toniosso (2014), a família e a escola enfrentam diversas dificuldades relacionadas à formação integral da criança. Entretanto, há muitos desafios quanto às responsabilidades de cada uma, já que é fundamental, para o bom desempenho da criança na vida escolar, que a família propicie à criança bem-estar em um ambiente de estímulo no convívio domiciliar.

É recorrente que, nos dias de hoje, a maior responsabilidade na educação da criança esteja voltada à escola, pois nesta o aluno encontra acalento, carinho e alimento. Conforme os anos foram passando, a população brasileira aumentou e devido a fatores de mudanças sociais na família, a escola torna-se pilar da educação do ser humano. Vale lembrar que cabe à família direcionar as crianças nos valores morais, afetivos e estimular-Ihe a cognição, pois esse processo se inicia em casa e continua na escola. A criança, portanto, inicia a vida escolar com bagagens cognitivas vividas no meio familiar.

\subsection{CRIANÇA E FAMÍLIA NO CONTEXTO DA EDUCAÇÃO INFANTIL}

Nesse período de Educação Infantil, podemos destacar a interação e o contato lúdico entre crianças e adultos, fora do núcleo familiar. Até os seis anos, a criança vive uma complexa fase de desenvolvimento, que compreende aspectos intelectuais, sociais, motores e emocionais. Esse processo está ligado às condições do ambiente em que a criança vive e se desenvolve e às relações outras com adultos com os quais a criança tem contato.

O papel da escola não se encerra em ser espaço agradável, em que a criança apenas brinca. É nodal que se constitua como ambiente estimulante, educativo e seguro. A formação docente também é crucial, já que professores acompanharão o desenvolvimento intenso de várias e plurais crianças ao mesmo tempo. Nesse

$\mathrm{RC}: 61320$

Disponível em: https://www.nucleodoconhecimento.com.br/educacao/estagio 
sentido, é papel da escola, entre outros, fomentar e propiciar uma base sólida, que constituirá o sujeito em formação.

Ao tratarmos da Educação Infantil, ressaltamos seu processo histórico de constituição. Em primeiro momento, havia um caráter assistencialista e de cuidado e, posteriormente, desenvolveu-se uma visão mais pedagógica. Nessa direção, a pessoa pedagoga tem preparo e formação para lidar e construir conhecimento com a criança, no processo educacional.

A discussão de problemáticas, tais como desrespeito, desmotivação e ausência de limites, permeia os debates sobre educação. A docência, nos últimos anos, tem assistido a uma precarização, que afeta a classe tanto fora quanto dentro das escolas. Na compreensão de Esteve (1999), o sistema de educação no Brasil, devido a mudanças sociais que o atingiram, não dispõe de recursos e capacidade que o tonem capaz de contemplar e atender às demandas sociais vigentes. $E$, quando se volta às demandas, o processo para tal é lento, que outras e demais problemáticas já surgem no contexto educacional. É necessário que discussões como estas circulem pela sociedade e pelo Estado e não apenas na escola.

É possível apontar que, das mudanças sociais, a que ocorre na família hoje é uma das mais significativas, pois a tradicionalidade tornou-se rara: a constituição pautada em pai, mãe e filhos mudou. Esse paradigma familiar, com divórcios e segundo casamento, cede lugar a outros modelos e configurações de família. Tais contextos acarretam, por vezes, sensações de insegurança e mesmo de abandono, visto que a imagem de pai e mães que cuidam cede lugar à de que gerenciam.

Essa sociedade de mudanças também exige, por vários fatores, que pais e mães arquem e lidem com posições no mercado de trabalho cada vez mais competitivas. Nesse sentido, a delimitação de papeis familiares era, antes, bem definida, mas hoje, também em virtude do trabalho, tais funções se confundem. Com isso, nota-se que crianças e adolescente, em muitos casos, estão sob cuidado de outros familiares, estranhos ou ainda de eletrônicos (televisão, celular, internet e afins).

RC: 61320

Disponível em: https://www.nucleodoconhecimento.com.br/educacao/estagio 
Nesse contexto, então, há uma série de sentimentos conflitantes nas relações entre pais e filho e entre os próprios pais. A culpa, pois, é um sentimento comum nesse entrave, que impede pais de negarem exigências dos filhos. Na tentativa de compensar a ausência, o pai, imbuído pela culpa, oferta os desejos da criança. $\mathrm{Na}$ mesma direção, a mãe não avalia corretamente as ações e atos do filho.

O sentimento da culpa, pelo fato de não estarem presente de modo integral e efetivo, leva pais a ignorarem o que ocorre com os filhos. Assim, cria-se uma situação em que pais e mães tornam-se reféns estão à mercê das próprias crianças. No receio de contrariar, junto à culpa, pais reforçam atos inadequados e, consequentemente, prejudicam tanto o desenvolvimento intelectual, quanto mental e emocional dos filhos. Quando a escola, nesse contexto, tenta intervir, tais conflitos se agravam e se acentuam, pois os pais, pelas problemáticas discutidas, transferem responsabilidades e deveres à escola, contudo não aceitam ver, tranquilamente, a função ser exercida pela escola. Sobre a relação de família e escola, podemos destacar que:

[...] os pais que não têm condições emocionais de suportar a sua parcela de responsabilidade, ou culpa, pelo mau rendimento escolar, ou algum transtorno de conduta do filho, farão de tudo, para encontrar argumentos e pinçar fatos, a fim de imputar aos professores que reprovaram o aluno, ou à escola como um todo o total responsabilidade pelo fracasso do filho (ZIMERMAN apud BOSSOLS, 2003, p.14)

Trazer a família para a discussão dos debates escolares é essencial, de modo que haja maior participação nos processos educacionais e que haja compartilhamento de responsabilidades entre escola, família e Estado.

Assim, observa-se que, em muitos casos a escola (e seus professores) acaba sendo sistematicamente desautorizada quando, na tentativa de educar, procura estabelecer limites e responsabilidades. O resultado desses sucessivos embates é que essas crianças e adolescentes acabam tornando-se testemunhas de um absurdo e infrutífero cabo-de-guerra, entre a sua escola e a sua família. E a situação pode assumir uma maior complexidade porque, conforme também explica Zimerman, "o próprio aluno, que não suporte reconhecer a responsabilidade por suas falhas, fará um sutil

$\mathrm{RC}: 61320$

Disponível em: https://www.nucleodoconhecimento.com.br/educacao/estagio 
jogo de intrigas que predisponha os pais contra os professores e a escola" (ZIMERMAM apud BOSSOLS, 2003, p.14)

A educação é, portanto, um processo que exige formação, esforço, paciência e tranquilidade. Nesse percurso, torna-se essencial saber ponderar e ter firmeza ao estabelecer limites e responsabilidades e evidenciar que direitos e deveres sempre estão juntos.

Para Paulo Freire, "A mudança é uma constatação natural da cultura e da história. O que ocorre é que há etapas, nas culturas, em que as mudanças se dão de maneira acelerada. É o que se verifica hoje. As revoluções tecnológicas encurtam o tempo entre uma e outra mudança" (2000, p.30). A sociedade vive diversas mudanças em um período curto, mudanças inclusive radicais. A escola e a família não estão alheias a tais mudanças. Ambas se movimentam junto a novos contextos e condições sociais, culturais e econômicos.

Ressaltamos a relevância da parceria entre família e escola, ainda mais pertinente nesse cenário de mudanças sociais. É importante que a família integre a vida escolar das crianças em todos os momentos, com uma participação permanente e construtiva.

Há contribuições que a família e a escola podem desempenhar, a fim de oferecer aos filhos/alunos espaços e ambientes propícios e saudáveis ao desenvolvimento educacional. Quanto à família, é necessário pensar a seleção da escola a partir de critérios que evidenciem a segurança e confiabilidade escolar em situações relevantes. Também, dialogar com os filhos sobre o conteúdo e, em geral, a vida escolar é importante para a melhora da educação. De mesmo modo, a família, ao cumprir regras e orientações da escola conscientemente e permitir aos filhos a decisão de problemas no ambiente escolar, contribui diretamente com o processo educacional. Quanto à escola, seguir determinada proposta pedagógica, discutida com pais e responsáveis, é um caminho possível de melhora, assim como fomentar a liberdade de expressão de alunos e considerá-la importante nos âmbitos do processo educacional. É crucial ainda que a escola se mantenha sempre aberta à

$\mathrm{RC}: 61320$

Disponível em: https://www.nucleodoconhecimento.com.br/educacao/estagio 
família frente às diversas situações desse processo. Por fim, a atualização de recursos pedagógicos e a formação continuada de professores são pontos nodais para construção de qualidade do processo educacional.

\section{RELATO DE OBSERVAÇÃO}

Durante o estágio supervisionado na Educação Infantil, observou-se que a professora estagiária chega às $12 \mathrm{~h} 15$ e permanece até $18 \mathrm{~h} 15$ no CEMEIS. Conversa com a estagiária da manhã (que inicia às $6 \mathrm{~h} 30$ e fica até 12h30) sobre algum recado que a professora regente da sala deixou. A professora regente da sala inicia às $7 \mathrm{~h}$ e vai até $11 \mathrm{~h}$, e, no período vespertino, das $13 \mathrm{~h}$ às $17 \mathrm{~h}$. O lanche se inicia às $14 \mathrm{~h} 30$ e vai até $15 \mathrm{~h}$, que é servido no refeitório. Em seguida, as crianças escovam os dentes, às $16 \mathrm{~h}$. Todos os dias as professoras levam as crianças ao parquinho ou ao campinho da escola.

Conforme as crianças foram chegando, a professora estagiária as recebia com pecinhas de montar, filme, madeirinhas, sucatas, brinquedos, bonecas e carrinhos. A professora regente da sala chegou às $13 \mathrm{~h}$ e iniciou suas aulas com roda de conversa com base no plano de ensino daquela semana (início em 15 de março de 2010). O tema da semana era as formas geométricas e a cores amarela, verde, vermelho e azul.

$\mathrm{Na}$ segunda-feira, a professora iniciou a aula com roda de conversa, na qual conversaram sobre circo, já que no dia quinze era o dia do circo. Trataram de como era o circo, do que nele havia, de quais animais existiam no circo e de quem já o conhecia etc. Percebi que as crianças interagiram com as professoras, que, em seguida, fizeram pinturas no rosto dos alunos. Logo depois, houve uma apresentação que contou com palhaços e mágicas, comemorando, assim, o dia do circo.

$\mathrm{Na}$ terça-feira, a professora trabalhou as formas geométricas: o círculo, o quadrado, o triangulo e o retângulo; e ainda as cores vermelha, amarela, azul e verde, já

RC: 61320

Disponível em: https://www.nucleodoconhecimento.com.br/educacao/estagio 
trabalhadas na semana anterior. O círculo era vermelho, quadrado, azul; o triangulo, amarelo; e o retângulo, verde. As crianças associaram que o vermelho é a cor do sangue e da cortina da sala; o azul é a cor da parede da sala e do céu; o amarelo, a cor do peixinho da sala e do sol; e o verde, a cor das folhas das árvores da escola. Em seguida, os alunos pegaram as formas geométricas na mão, enquanto a professora ia perguntando qual forma e qual cor eles estavam segurando. Houve, assim, interação entre professoras e alunos.

$\mathrm{Na}$ quarta-feira, as professoras passaram atividade com giz de cera, com os quais as crianças iam pintar o círculo de vermelho e o triangulo de amarelo. As professoras organizaram as crianças no chão e todas pintaram. Percebi, então, que as crianças estavam bastante concentradas e que a coordenação motora deles estava muito boa para a idade, três anos.

$\mathrm{Na}$ quinta-feira, as professoras passaram atividades com o giz de cera e explicaram sobre os limites dos espaços que as crianças tinham de pintar: o quadrado de azul e o retângulo de verde. Em seguida, organizaram as crianças no chão, deixando-as à vontade para que pintassem os desenhos, e elas pintaram em aproximadamente 15 minutos

$\mathrm{Na}$ sexta-feira, era dia de cineminha na escola. Todas as crianças e professores da escola se reuniram na primeira sala do CEMEIS, em frente à Coordenação. O filme, Procurando Nemo, teve início às $13 \mathrm{~h} 15$ e foi até $15 \mathrm{~h} 40$ e era ótimo, porém muito extenso para eles. Em um certo momento, as crianças ficaram cansadas de assistir ao filme e bastante agitadas, pois o filme tem em média duas horas de duração. Em seguida, foram lanchar, depois escovaram os dentes e foram ao parquinho. Os pais começaram a chegar para buscar os alunos às $16 \mathrm{~h} 20$.

Percebi que há boa socialização tanto com professores e alunos, quanto entre alunos. Os funcionários, desde o guarda da escola, as faxineiras, as cozinheiras, professores e até toda a coordenação trabalham em equipe, cuidando dos alunos, dando-lhes assim segurança e apoio.

RC: 61320

Disponível em: https://www.nucleodoconhecimento.com.br/educacao/estagio 
Para a realização do plano de ensino semanal, as professoras se reúnem na sextafeira com a diretora e a coordenadora. Debatem o tema segundo as pastas que foram entregues a elas no início das aulas. Conforme vão debatendo o tema, vão surgindo ideias e, assim, fazem os seus planos de aula.

\section{RELATO DE REGÊNCIA}

$\mathrm{Na}$ regência, começamos com o projeto páscoa. Primeiro teve a roda de conversa, momento no qual expliquei o verdadeiro sentindo da páscoa: a ressurreição e o valor do perdão e da desculpa. Trabalhamos com músicas referentes à páscoa e aos símbolos pascoais, como o sino, a vela, o ovo e o coelho.

Desenhamos junto às crianças os quatro símbolos da páscoa, que os pintaram com tinta guache. A atividade reforçou, assim, os significados dos símbolos e trabalhou a coordenação motora dos alunos.

Trabalhamos com os alunos um filme de 10 minutos sobre a páscoa, em que os coelhinhos faziam os ovos de chocolate e os pintavam. No filme, todos os ovos eram feitos pelos coelhinhos, evocando, assim, a imaginação das crianças. Ao final, fizemos perguntas sobre o que tinha no filme, e todos surpreenderam com as respostas.

Trabalhamos pinturas com tinta guache e colagem com EVA; noção de espaço e tamanho (grande, médio e pequeno); a coordenação motora; e as cores vermelha e azul. Os alunos aprenderam a diferença do ovo de galinha e o de páscoa, assim como a divisão com os colegas, pois, ao comer os ovos de galinha, colocamos na frente dos alunos um ovo de páscoa e pedimos o que iríamos fazer se só havia um ovo de páscoa. As crianças tiveram várias ideias, dentre as quais uma me chamou para perto e me falou: "Prof vamos comer eu e você". Continuamos perguntando o que iríamos fazer com o ovo de páscoa, até que uma criança disse "vamos dividir Prof". Então começamos a contar quantas crianças tinham e quantos professores e abrimos o ovo. Fui contando os pedaços e depois todos comemos.

RC: 61320

Disponível em: https://www.nucleodoconhecimento.com.br/educacao/estagio 
Fizemos atividades com as cascas dos ovos de galinha, que consistiu em as crianças colarem as casquinhas no desenho de um ovo, de modo trabalhar a coordenação motora e noção de espaço.

Anda, levamos dois coelhos à escola e reproduzimos pegadas do animal na sala. Quando as crianças voltaram do lanche, ficaram impressionadas com as pegadas. Colocamos também ovinhos de chocolate em uma cestinha, que as crianças acharam e, com isso, ficaram eufóricas. Depois, falei-lhes que precisávamos procurar os coelhos, que estavam atrás das almofadas. Em seguida, ao serem encontrados, as crianças ficaram impressionadas, e todo mundo queria pegá-los. Todas passaram as mãos nos coelhos e Ihes cantaram a música do coelhinho da páscoa. Após isso, pedi para que eles se despedissem dos coelhos e, em seguida, mostrei as cores do papel embrulhado nos ovinhos. Todos falaram certo e, depois, pedimos a cada criança que desejasse feliz páscoa umas às outras enquanto estávamos entregando os ovinhos.

A escola promove a festinha de aniversário, que acontece em todas as últimas quintas-feiras do mês. As crianças aniversariantes tiram fotos e brincam no pulapula. Há uma festinha, com bolo, salgadinho, torta salgada e brigadeiro, em que os aniversariantes brincam junto a todos os colegas. As crianças gostam e se divertem muito nesse dia.

Trabalhamos também o projeto "Meu corpo", que funciona a partir de uma roda de conversa que trata do corpo da higiene etc. Desenhamos uma criança em cima do papel pardo e, depois, junto às crianças, começamos a colocar as partes do corpo. Eles iam falando o que faltava, e nós íamos colocando. Em seguida, cantamos a música da Xuxa "cabeça, ombro, joelho e pé".

No último dia de estágio, preocupamo-nos de que fosse o mais divertido possível. Fizemos brincadeiras, dançamos e comemos, na sala, o lanche que tínhamos trazido de casa. Fomos ao parque, corremos e brincamos bastante.

RC: 61320

Disponível em: https://www.nucleodoconhecimento.com.br/educacao/estagio 


\section{CONSIDERAÇÕES FINAIS}

Ao término da realização dos estágios supervisionados e, consequentemente, do curso, percebo o quanto isso foi significativo para minha vida profissional e até mesmo o crescimento enquanto humana.

No estágio da Educação Infantil, vimos o quanto o professor e a família são importantes para o desenvolvimento do aluno, que sente um profundo carinho pelo seu professor, acreditando mais nas palavras dele do que nas palavras dos seus pais. Ainda nessa fase, os estímulos podem ser comparados como medicamentos possibilitando o maior desenvolvimento administrado na dose certa.

Sendo assim, podemos perceber o quanto foram importantes os estágios no decorrer do curso de Pedagogia. Tivemos a oportunidade de ver, perceber e sentir a realidade dos professores e gestores nas escolas e as dificuldades que enfrentam todos os dias. Uma coisa impressionante é o carinho que eles sentem pelos alunos e pela profissão que escolheram, a de ser o "mediador do conhecimento".

\section{REFERÊNCIAS}

ABREU, L, C et al. A epistemologia genética de Piajet e o construtivismo. Revista brasileira de crescimento e desenvolvimento humano, vol.20, n.2, 2010, p. 361366.

BRASIL. Lei de Deretrizes e Bases da Educação Nacional, LDB. 9394/1996.

CREPALDI, E. M. F. A importância da família na escola para a construção do desenvolvimento do aluno. In: Congresso nacional da educação, 13, 2017, Curitiba. Anais eletrônicos. p. 11732-11744. Disponível em: https://educere.bruc.com.br/arquivo/pdf2017/25972_13983.pdf. Acesso em: 11 out. 2020.

RC: 61320

Disponível em: https://www.nucleodoconhecimento.com.br/educacao/estagio 
ESTEVE, J, M. O mal-estar docente: a sala de aula e os professores. São Paulo: EDUSC, 1999.

GADOTTI, M; ROMÃO, J. E; (orgs). Educação de Jovens e Adultos: Teoria, prática e proposta. São Paulo: Cortez: Instituição Paulo Freire, 2001.

KAMII, C. Jogos em grupo na educação infantil: Implicações da teoria de Piaget. Tradução Maria Célia Dias Carrasqueira; prefácio Jean Piaget. São Paulo: Trajetória Cultural, 1999.

KISHIMOTO, T. M. O jogo e a Educação Infantil. São Paulo: Pioneira Thomson Learning, 2003.

LOPES, M. G. Jogos na educação; criar, fazer, jogar. 3ed. São Paulo, Cortez, 2000

FREIRE, Paulo. Pedagogia da Indignação: cartas pedagógicas e outros escritos. São Paulo: UNESP, 2000.

SANTOS, L. R. TONIOSSO, J. P. A importância da relação escola-família. Cadernos de Educação: Ensino e Sociedade, Bebedouro-SP, vol.1, n.1 p.122134, 2014.

ZIMERMAN, David Epelbaum. A Psicanálise e a Escola. In: BASSOLS, Ana Margareth S. et al. (org.). Saúde Mental na escola: uma abordagem multidisciplinar. Porto Alegre: Meditação, 2003. p. 9-17.

RC: 61320

Disponível em: https://www.nucleodoconhecimento.com.br/educacao/estagio 


\section{ANEXOS}

\section{PLANO DE ENSINO E PLANO (S) DE AULA (S)}

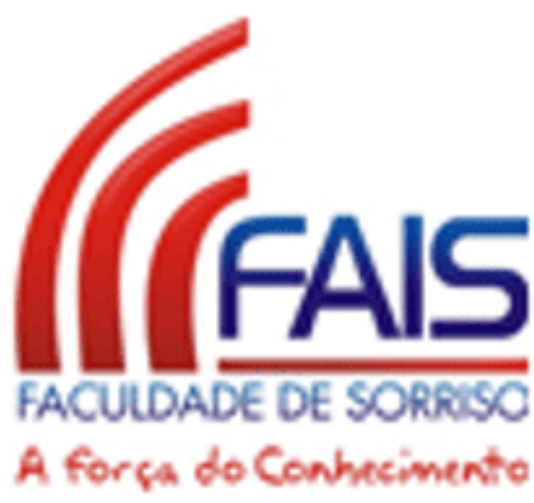

\section{FACULDADE DE SORRISO- FAIS}

Plano de Ensino

Acadêmico: Francielli Jaqueline de Paula

Professor (a) Dirlei Albiero Andrioni Instituição conveniada: CEMEIS São Domingos

Disciplina: Educação Infantil

Período: Matutino

Carga Horária: 100 horas

Serie: Maternal II

1 Objetivo geral da disciplina

Desenvolver atividades de páscoa com os alunos, ressaltando a importância da páscoa e seus significados. Trabalhar o projeto "Meu corpo" para que os alunos conheçam o próprio corpo e para ressaltar importância da higiene corporal.

\section{Objetivo específico}

Evidenciar aos alunos a importância da páscoa, os seus significados e ressaltar a importância do perdão. Mostrar aos alunos a importância do corpo e da higiene corporal.

RC: 61320

Disponível em: https://www.nucleodoconhecimento.com.br/educacao/estagio 
3 Conteúdo programático

Páscoa

Símbolos da Páscoa

Higiene

Partes do corpo

4 Estratégias

Diálogo

Música

Teatrinho

Atividade recorte e colagem

Pintura

Massinha

Educação Física

Festinha de Aniversário

Hora do Lanche

Hora da Fruta

Parquinho

Campinho

Brincadeiras

RC: 61320

Disponível em: https://www.nucleodoconhecimento.com.br/educacao/estagio 


\section{Historinhas}

\section{Filminhos}

\section{Cineminha}

Pecinha de Montar

Quebra-cabeça

Madeirinha

Brinquedos, bonecas e carrinho.

\section{Avaliação}

Participação dos alunos nas atividades, desempenho nas atividades propostas, socialização entre eles, cuidados com os brinquedos e a criatividade de cada um.

6 Bibliografia:

\section{Assinaturas}

Acadêmico Estagiário

Professor Supervisor

Coordenador do Curso:

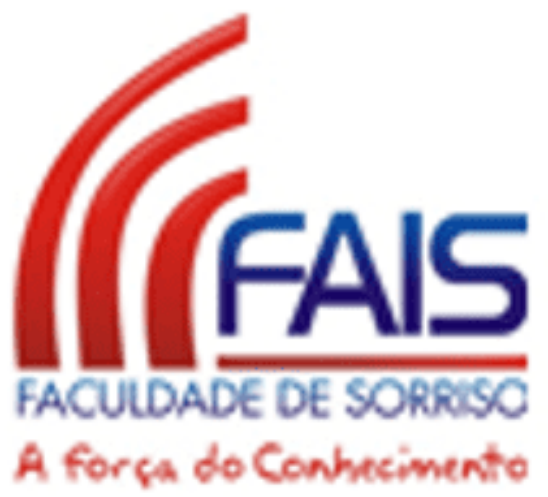

RC: 61320

Disponível em: https://www.nucleodoconhecimento.com.br/educacao/estagio 


\section{FACULDADE DE SORRISO- FAIS}

Plano de Aula

Acadêmico: Francielli Jaqueline de Paula

Professor (a) Dirlei Albiero Andrione Instituição conveniada: CEMEIS São Domingos

Disciplina: Educação Infantil

Período: Matutino Carga Horária: 100 horas

Serie: Maternal II

1 Objetivo geral da disciplina

Ressaltar o verdadeiro significado da Páscoa.

2 Objetivo específico

Mostrar o significado da páscoa e ensinar aos alunos a música do coelhinho da Páscoa.

3 Conteúdo programático

Projeto Páscoa

4 Estratégias

Receber as crianças com pecinha de montar,

1h30 Roda de conversa onde irão se sentar em círculos e irei explicar o verdadeiro significado da páscoa. Em sequência, ensinar-lhes a cantar a música (Coelhinho da Páscoa). 2h30 Lanche.

3h10 Escovar os dentes

Fruta

Educação Física

\section{Avaliação}

Participação dos alunos nas atividades, desempenho nas atividades propostas, socialização entre eles, cuidados com os brinquedos e a

RC: 61320

Disponível em: https://www.nucleodoconhecimento.com.br/educacao/estagio 
criatividade de cada um.

6 Bibliografia

Livros e figuras que representem a páscoa.

\section{Assinaturas}

Acadêmico Estagiário

Professor Supervisor

Docente da Disciplina

Coordenador do Curso:

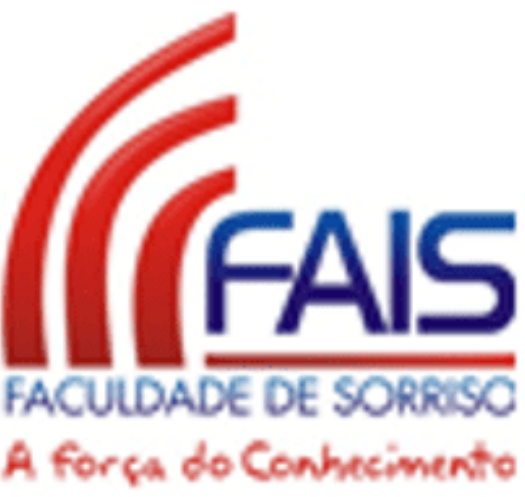

FACULDADE DE SORRISO- FAIS

Plano de Aula

Acadêmico: Francielli Jaqueline de Paula

Professor (a) Dirlei Albiero Andrione Instituição conveniada: CEMEIS São Domingos

Disciplina: Educação Infantil

Período: Matutina Carga Horária: 100 horas

Serie: Maternal II

1 Objetivo geral da disciplina

Frisar a importância do amor, do perdão e da solidariedade.

2 Objetivo específico

Trabalhar o renascimento de Cristo.

3 Conteúdo programático

Projeto Páscoa.

RC: 61320

Disponível em: https://www.nucleodoconhecimento.com.br/educacao/estagio 


\section{Estratégias}

\section{Educação Física}

Lanche

3h10 Escovar os dentes

3h30 Filminho sobre a páscoa, com duração de quinze minutos e, em seguida, conversar sobre.

\section{Frutas}

\section{Educação Física}

\section{Avaliação}

Participação dos alunos nas atividades, desempenho nas atividades propostas, socialização entre eles, cuidados com os brinquedos e a criatividade de cada um.

\section{Bibliografia}

\section{Filme}

\section{Assinaturas}

Acadêmico Estagiário

Professor Supervisor

Docente da Disciplina

Coordenador do Curso:

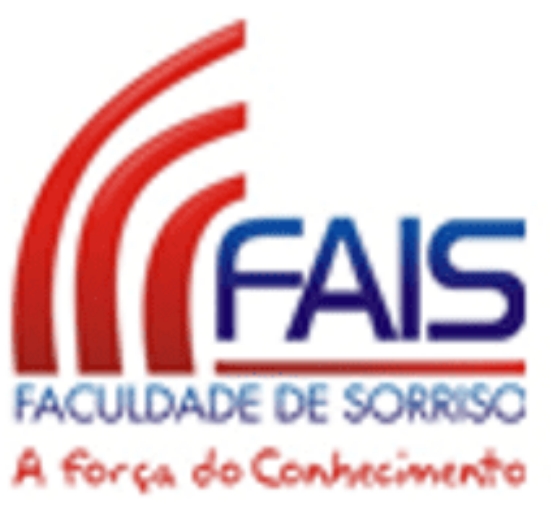

RC: 61320

Disponível em: https://www.nucleodoconhecimento.com.br/educacao/estagio 


\section{FACULDADE DE SORRISO- FAIS}

Plano de Aula

Acadêmico: Francielli Jaqueline de Paula

Professor (a) Dirlei Albiero Andrione Instituição conveniada: CEMEIS São Domingos

Disciplina: Educação Infantil

Período: Matutina Carga Horária: 100 horas

Serie: Maternal II

1 Objetivo geral da disciplina

Reforçar os significados dos símbolos da Páscoa.

2 Objetivo específico

Trabalhar os símbolos e seus significados.

3 Conteúdo programático

Projeto Páscoa

4 Estratégias

Receber as crianças com brinquedos

1h30 atividade onde irão sentar e irei explicar a atividade. Em seguida se reunirão em quatro grupos nos quais irão pintar com o dedo os símbolos desenhados no papel pardo, dentre eles a vela, o sino, o coelho e o ovo.

Lanche

3h10 Escovar os dentes

Frutas

Parquinho

5 Avaliação

Participação dos alunos nas atividades, desempenho nas atividades propostas, socialização entre eles, cuidados com os brinquedos e a

RC: 61320

Disponível em: https://www.nucleodoconhecimento.com.br/educacao/estagio 
criatividade de cada um.

6 Bibliografia

Papel pardo e tinta guache

Assinaturas

Acadêmico Estagiário

Professor Supervisor

Docente da Disciplina

Coordenador do Curso:

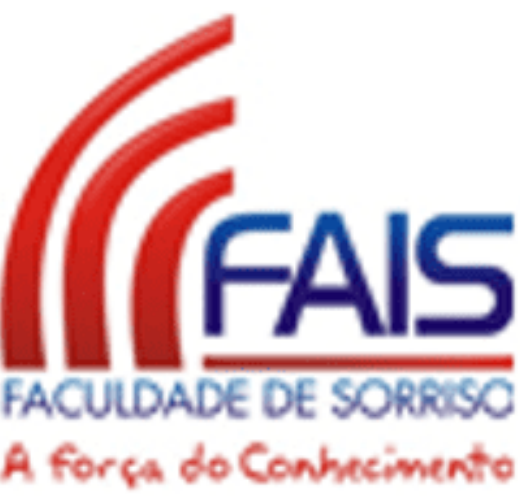

FACULDADE DE SORRISO- FAIS

Plano de Aula

Acadêmico: Francielli Jaqueline de Paula

Professor (a) Dirlei Albiero Andrione Instituição conveniada: CEMEIS São Domingos

Disciplina: Educação Infantil

Período: Matutina Carga Horária: 100 horas

Serie: Maternal II

1 Objetivo geral da disciplina

Trabalhar coordenação motora fina, noção de tamanho (grande, pequeno e médio) e as cores.

2 Objetivo específico

Noção de tamanho e as cores.

3 Conteúdo programático

RC: 61320

Disponível em: https://www.nucleodoconhecimento.com.br/educacao/estagio 
Projeto Páscoa.

4 Estratégias

Receber as crianças com sucatas.

1h30 Atividade na qual irão se sentar e irei explicá-la. Mostrarei ovos de codorna, galinha e avestruz, ressaltando os tamanhos. Em seguida cada um receberá uma folha sulfite, que estará desenhada com três ovos (o grande o pequeno e o médio). Eles pintarão de vermelho o ovo grande e colarão EVA azul no ovo pequeno e deixarão em branco o ovo médio.

Lanche

Educação física

Fruta

Parquinho

5 Avaliação

Participação dos alunos nas atividades, desempenho nas atividades propostas, socialização entre eles, cuidados com os brinquedos e a criatividade de cada um.

6 Bibliografia

Folha sulfite, EVA, giz de cera.

Assinaturas

Acadêmico Estagiário

Professor Supervisor

Docente da Disciplina

Coordenador do Curso:

RC: 61320

Disponível em: https://www.nucleodoconhecimento.com.br/educacao/estagio 


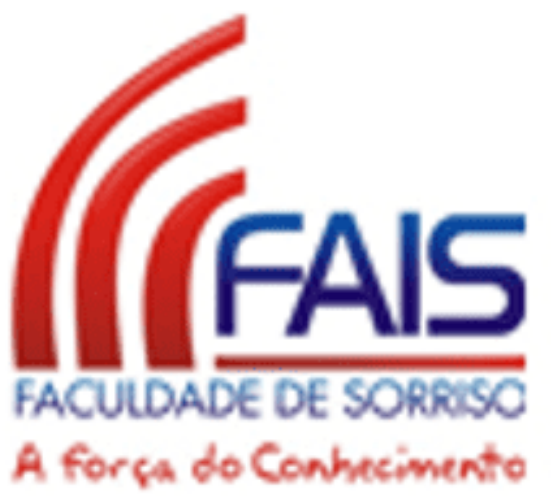

FACULDADE DE SORRISO- FAIS

Plano de Aula

Acadêmico: Francielli Jaqueline de Paula

Professor (a) Dirlei Albiero Andrione Instituição conveniada: CEMEIS São

\section{Domingos}

Disciplina: Educação Infantil

Período: Matutina

Carga Horária: 100 horas

Serie: Maternal II

\section{Objetivo geral da disciplina}

Fazer com que eles saibam diferenciar o ovo de galinha e o de chocolate, trabalhando também a divisão dos alimentos.

2 Objetivo específico

Fazer com que eles aprendam a diferença dos ovos e o valor de dividir a comida.

3 Conteúdo programático

Projeto Páscoa.

4 Estratégias

Receber as crianças com madeirinhas

Lanche

RC: 61320

Disponível em: https://www.nucleodoconhecimento.com.br/educacao/estagio 


\section{3h10 Escovar os dentes}

3h50 Atividade na qual irão se sentar em círculo, e explicarei o que é o ovo de galinha e como é o ovo de páscoa. Em seguida, repartiremos o ovo de galinha ao meio e todos comerão. Depois colocarei na frente deles um ovo de chocolate, para trabalhar assim a divisão dos alimentos.

\section{Avaliação}

Participação dos alunos nas atividades, desempenho nas atividades propostas, socialização entre eles, cuidados com os brinquedos e a criatividade de cada um.

6 Bibliografia

Ovos de galinha e um ovo de chocolate.

Assinaturas

Acadêmico Estagiário

Professor Supervisor

Docente da Disciplina

Coordenador do Curso:

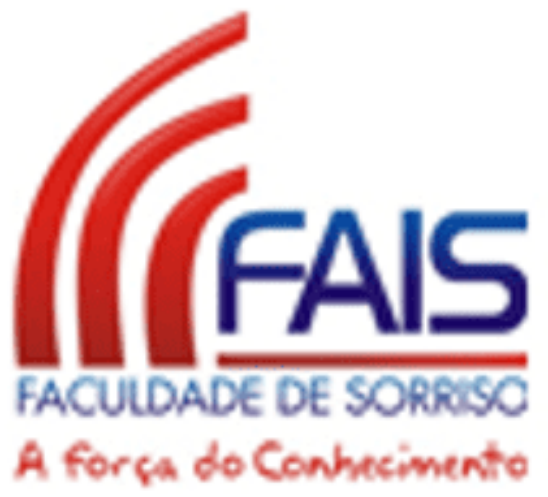

FACULDADE DE SORRISO- FAIS

Plano de Aula

Acadêmico: Francielli Jaqueline de Paula

Professor (a) Dirlei Albiero Andrione Instituição conveniada: CEMEIS São Domingos

$\mathrm{RC}: 61320$

Disponível em: https://www.nucleodoconhecimento.com.br/educacao/estagio 
Disciplina: Educação Infantil

Período: Matutina

Carga Horária: 100 horas

Serie: Maternal II

1 Objetivo geral da disciplina

Trabalhar a coordenação motora fina e noção de espaço do desenho e ensinar aos alunos que podem utilizar as cascas de ovo.

2 Objetivo específico

Que aprendam a reutilização das cascas de ovos e coordenação motora fina.

3 Conteúdo programático

Projeto Páscoa.

4 Estratégias

Receber as crianças com pecinha

1h30 Atividade na qual irão se sentar em círculo, para eu explicá-la. Em seguida vou dar-lhes uma folha para cada um, que estará desenhada com um ovo. Eles terão que colar as cascas dos ovos de galinha usados na semana passada com cola branca.

Lanche

3h10 Escovar os dentes

Frutas

Educação Física.

5 Avaliação

Participação dos alunos nas atividades, desempenho nas atividades propostas, socialização entre eles, cuidados com os brinquedos e a criatividade de cada um.

6 Bibliografia

Casquinha de ovo, folha sulfite e cola branca.

RC: 61320

Disponível em: https://www.nucleodoconhecimento.com.br/educacao/estagio 


\section{Assinaturas}

Acadêmico Estagiário

Professor Supervisor

Docente da Disciplina

Coordenador do Curso:

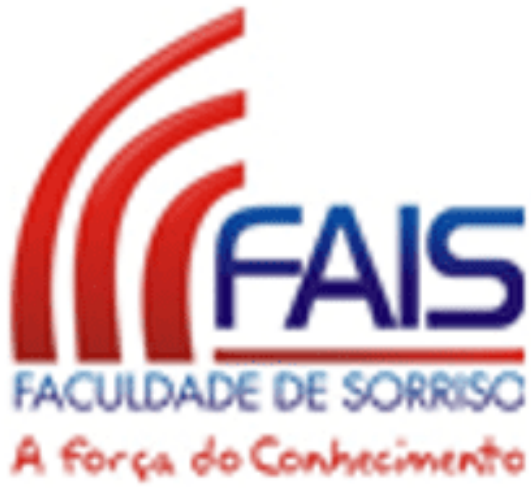

FACULDADE DE SORRISO- FAIS

Plano de Aula

Acadêmico: Francielli Jaqueline de Paula

Professor (a) Dirlei Albiero Andrione Instituição conveniada: CEMEIS São Domingos

Disciplina: Educação Infantil

Período: Matutina

Carga Horária: 100 horas

Serie: Maternal II

1 Objetivo geral da disciplina

Ressaltar o mundo mágico da imaginação das crianças.

2 Objetivo específico

Mostrar que a imaginação das crianças deve ser considerada.

3 Conteúdo programático

Projeto Páscoa.

4 Estratégias

Educação Física

RC: 61320

Disponível em: https://www.nucleodoconhecimento.com.br/educacao/estagio 


\section{Lanche}

3h10 As crianças vão entrar na sala e ver pegadas de coelho. Vamos procurar os coelhos. Estarão numa cestinha ovinhos de chocolate para cada um dos alunos. Depois cada um vai desejar Feliz Páscoa para os seus colegas.

\section{Educação Física}

\section{Avaliação}

Participação dos alunos nas atividades, desempenho nas atividades propostas, socialização entre eles, cuidados com os brinquedos e a criatividade de cada um.

\section{Bibliografia}

Coelho e ovinhos de chocolate.

Assinaturas

Acadêmico Estagiário

Professor Supervisor

Docente da Disciplina

Coordenador do Curso:

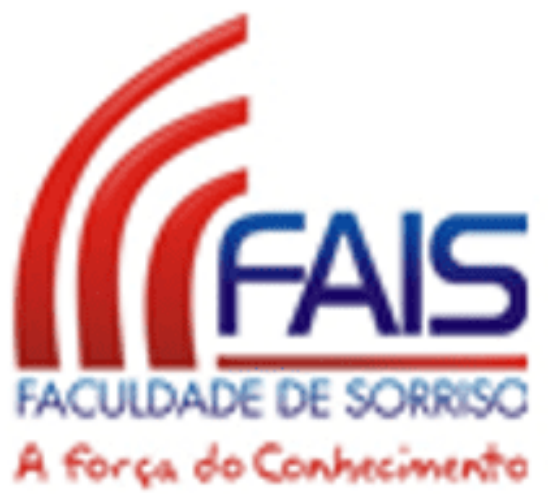

FACULDADE DE SORRISO- FAIS

Plano de Aula

Acadêmico: Francielli Jaqueline de Paula

$\mathrm{RC}: 61320$

Disponível em: https://www.nucleodoconhecimento.com.br/educacao/estagio 
Professor (a) Dirlei Albiero Adrione Instituição conveniada: CEMEIS São Domingos

Disciplina: Educação Infantil

Período: Matutina Carga Horária: 100 horas

Serie: Maternal II

1 Objetivo geral da disciplina

A confraternização das crianças.

2 Objetivo específico

A socialização

3 Conteúdo programático

Projeto Páscoa

4 Estratégias

Receber as crianças com brinquedos

2h Brincar no Pula-Pula

3h Festinha de aniversario

Frutas

Parquinho

5 Avaliação

Participação dos alunos nas atividades, desempenho nas atividades propostas, socialização entre eles, cuidados com os brinquedos e a criatividade de cada um.

6 Bibliografia

Assinaturas

Acadêmico Estagiário

Professor Supervisor

Docente da Disciplina

Coordenador do Curso:

RC: 61320

Disponível em: https://www.nucleodoconhecimento.com.br/educacao/estagio 


\section{(rFAIS \\ FACULDADE DE SORESC \\ A forsan do Conbecimento}

FACULDADE DE SORRISO- FAIS

Plano de Aula

Acadêmico: Francielli Jaqueline de Paula

Professor (a) Dirlei Albiero Andrione Instituição conveniada: CEMEIS São Domingos

Disciplina: Educação Infantil

Período: Matutina

Carga Horária: 100 horas

Serie: Maternal II

1 Objetivo geral da disciplina

Trabalhar com as crianças o projeto "Meu corpo" para que os alunos conheçam o próprio corpo, ressaltando a higiene corporal.

2 Objetivo específico

Estimular os alunos a conhecerem as partes do corpo e a higiene corporal.

3 Conteúdo programático

Projeto "Meu corpo"

4 Estratégias

Receber as crianças com brinquedos

1h30 Atividade na qual vamos nos sentar em círculo e vamos todos dizer o que é cada parte do corpo, desde o pé até à cabeça. Em seguida vamos deitar uma criança em cima do papel pardo, para desenha lá. Depois vamos

RC: 61320

Disponível em: https://www.nucleodoconhecimento.com.br/educacao/estagio 
colocar as partes do corpo que falta, como olho, boca, nariz etc. Falaremos da importância da higiene e vamos simular um banho, lavando todas as partes do corpo.

Lanche

3h10 Escovar os dentes

Frutas

Parquinho

5 Avaliação

Participação dos alunos nas atividades, desempenho nas atividades propostas, socialização entre eles, cuidados com os brinquedos e a criatividade de cada um.

6 Bibliografia

Papel pardo e pincel.

Assinaturas

Acadêmico Estagiário

Professor Supervisor

Docente da Disciplina

Coordenador do Curso:

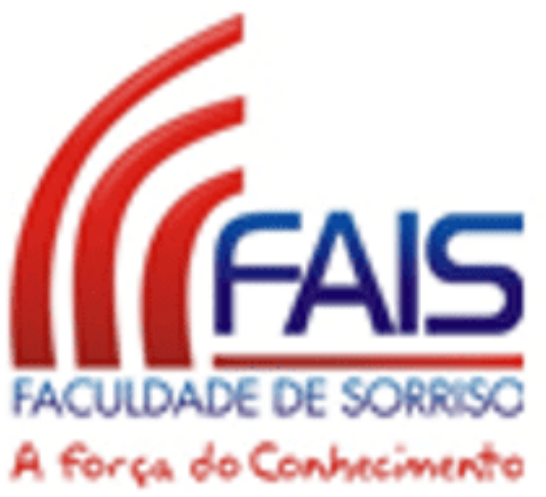

FACULDADE DE SORRISO- FAIS

RC: 61320

Disponível em: https://www.nucleodoconhecimento.com.br/educacao/estagio 
Plano de Aula

Acadêmico: Francielli Jaqueline de Paula

Professor (a) Dirlei Albiero Andrione Instituição conveniada: CEMEIS São Domingos

Disciplina: Educação Infantil

Período: Matutina

Carga Horária: 100 horas

Serie: Maternal II

1 Objetivo geral da disciplina

Confraternização

2 Objetivo específico

Agradecer a todos os alunos pelo carinho recebido pela professora estagiária.

3 Conteúdo programático

Confraternização

4 Estratégias

Educação Física

Lanche especial

3h10 Escovar os dentes

3h30 Brincadeiras, músicas e dança.

Frutas

Educação Física.

5 Avaliação

Participação dos alunos nas atividades, desempenho nas atividades propostas, socialização entre eles, cuidados com os brinquedos e a criatividade de cada um.

6 Bibliografia

RC: 61320

Disponível em: https://www.nucleodoconhecimento.com.br/educacao/estagio 
Lanche, música e brincadeiras

\section{Assinaturas}

Acadêmico Estagiário

Professor Supervisor

Docente da Disciplina

\section{Coordenador do Curso:}

\section{FOTOS DAS ATIVIDADES DE REGÊNCIA}

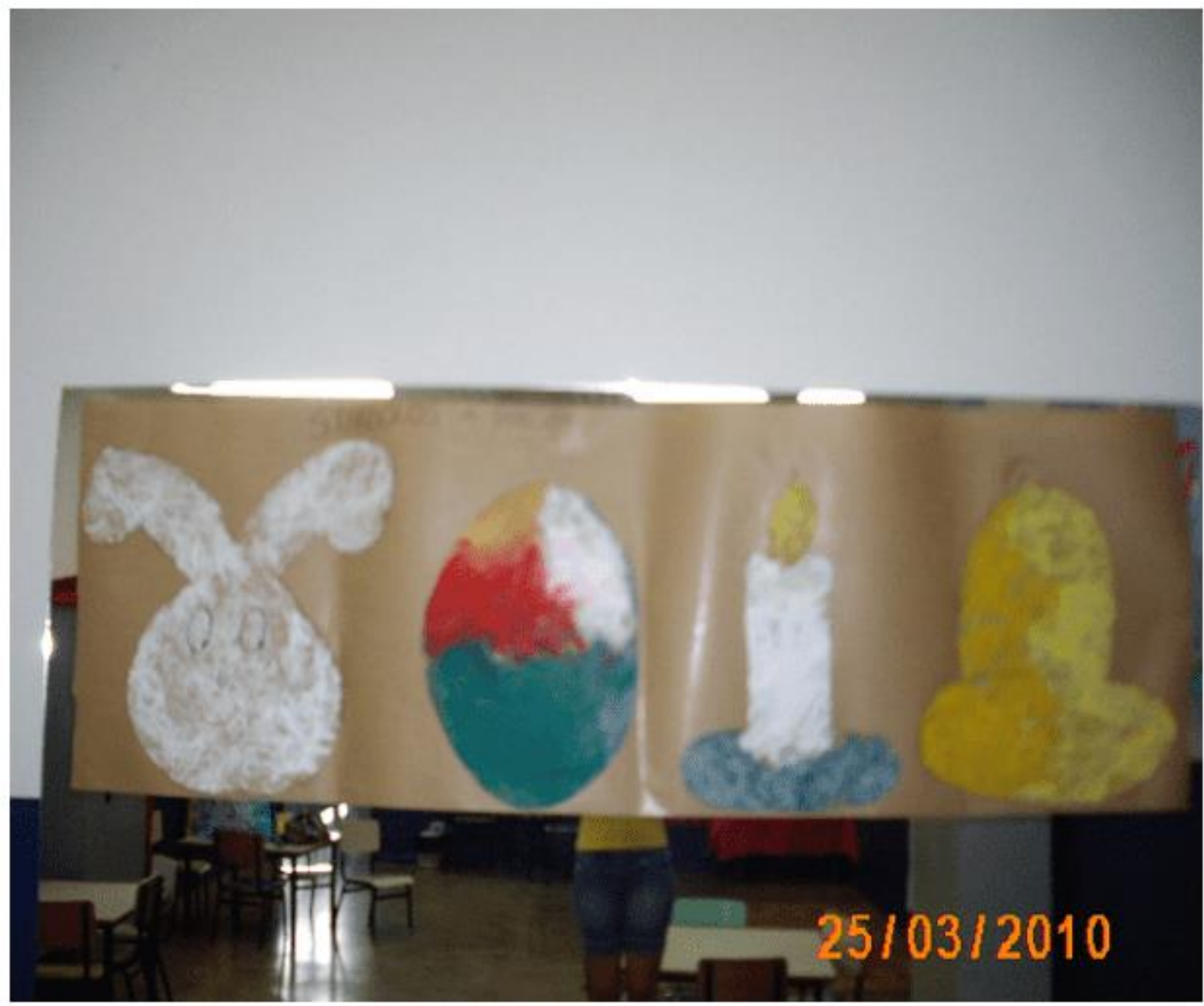

Fonte: Arquivo pessoal

RC: 61320

Disponível em: https://www.nucleodoconhecimento.com.br/educacao/estagio 


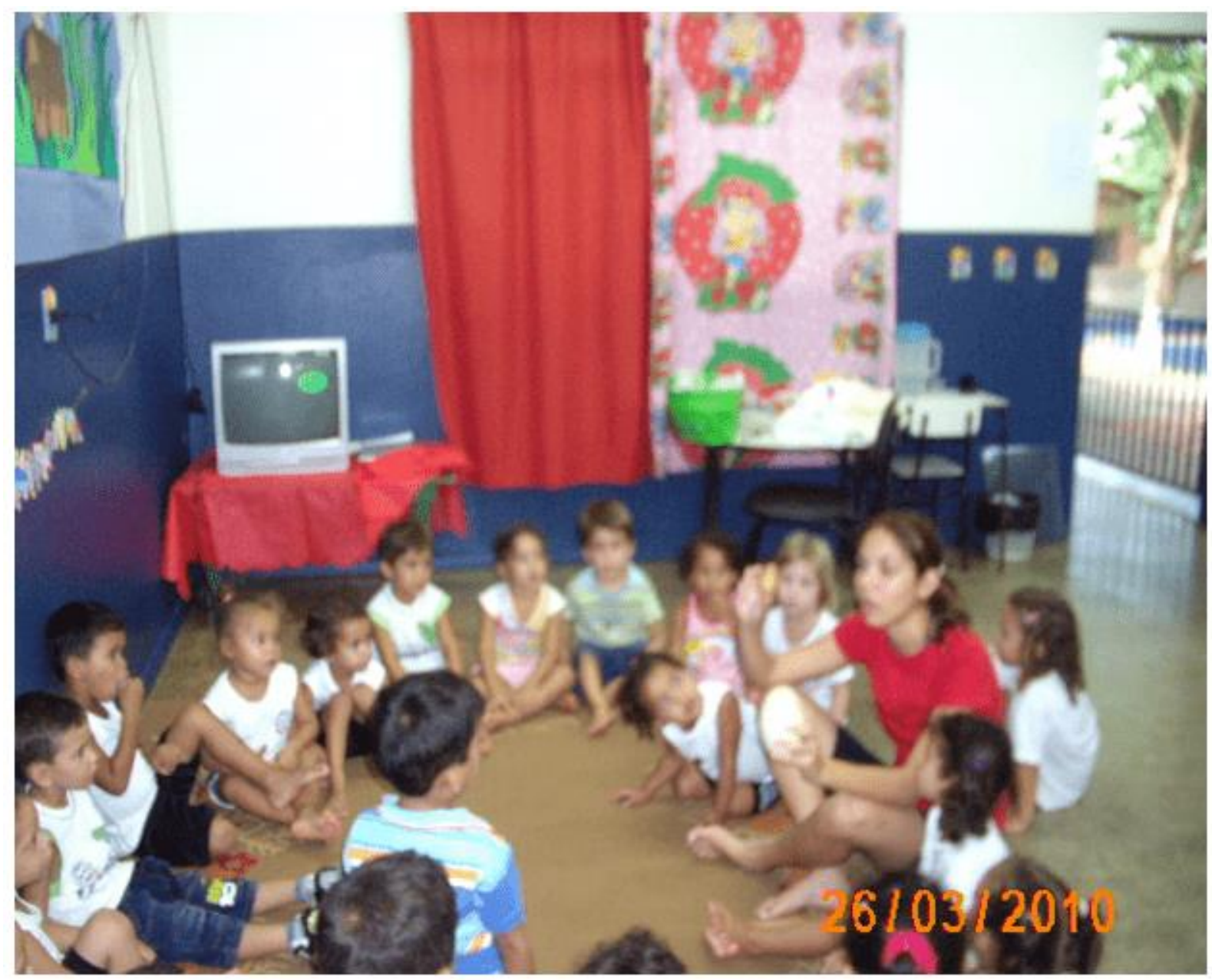

Fonte: Arquivo pessoal

$\mathrm{RC}: 61320$

Disponível em: https://www.nucleodoconhecimento.com.br/educacao/estagio 


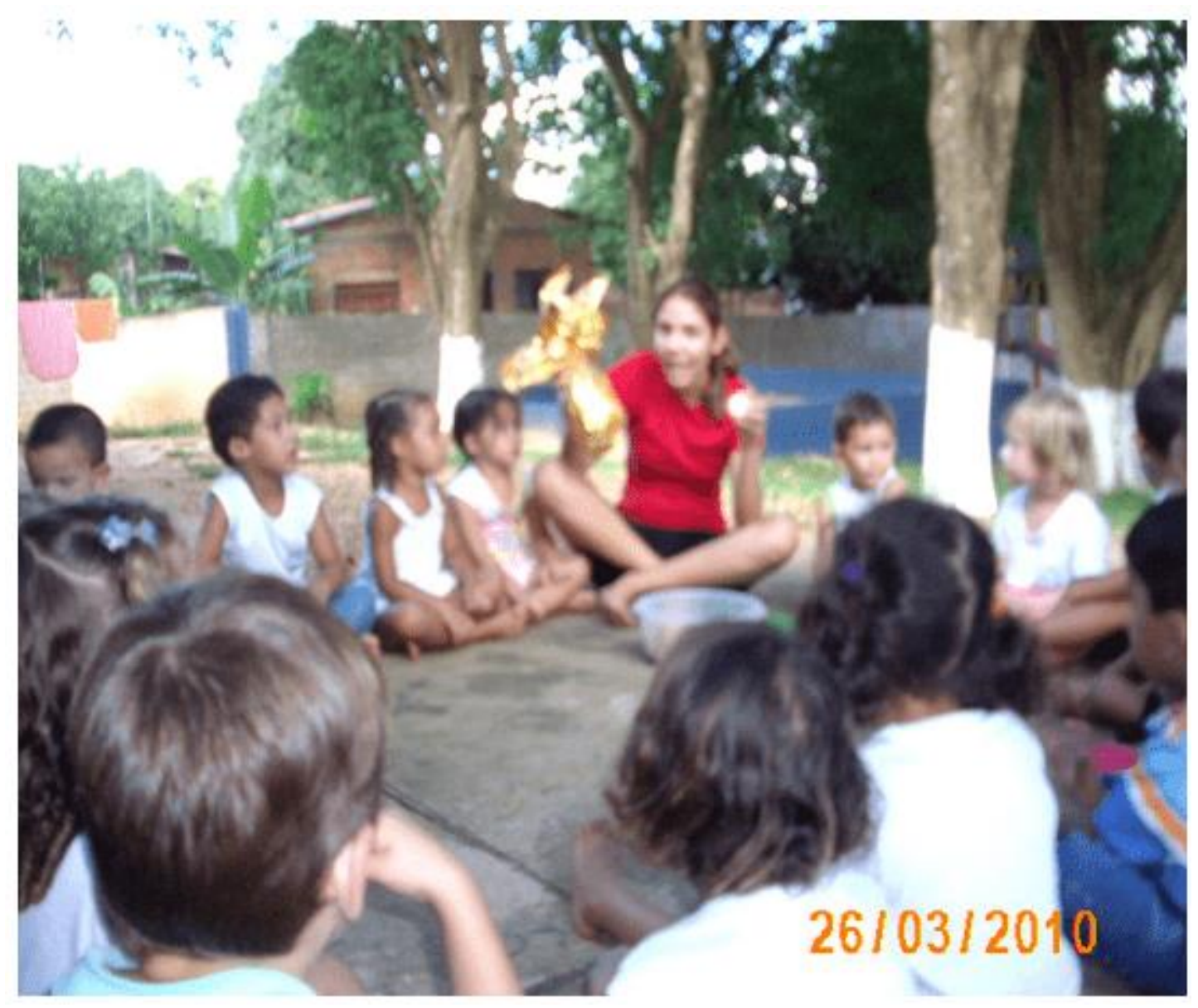

Fonte: Arquivo pessoal

RC: 61320

Disponível em: https://www.nucleodoconhecimento.com.br/educacao/estagio 


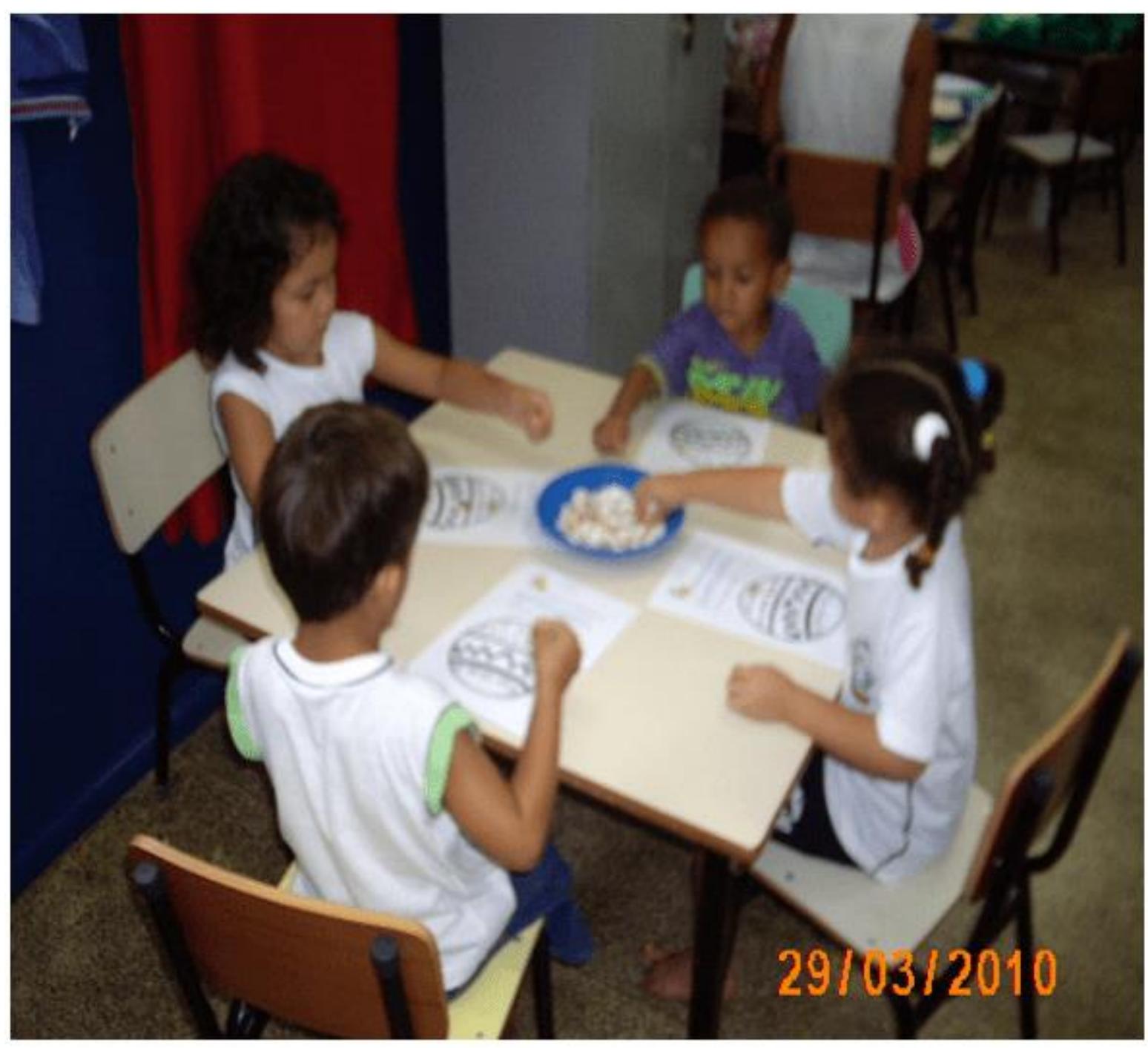

Fonte: Arquivo pessoal

RC: 61320

Disponível em: https://www.nucleodoconhecimento.com.br/educacao/estagio 


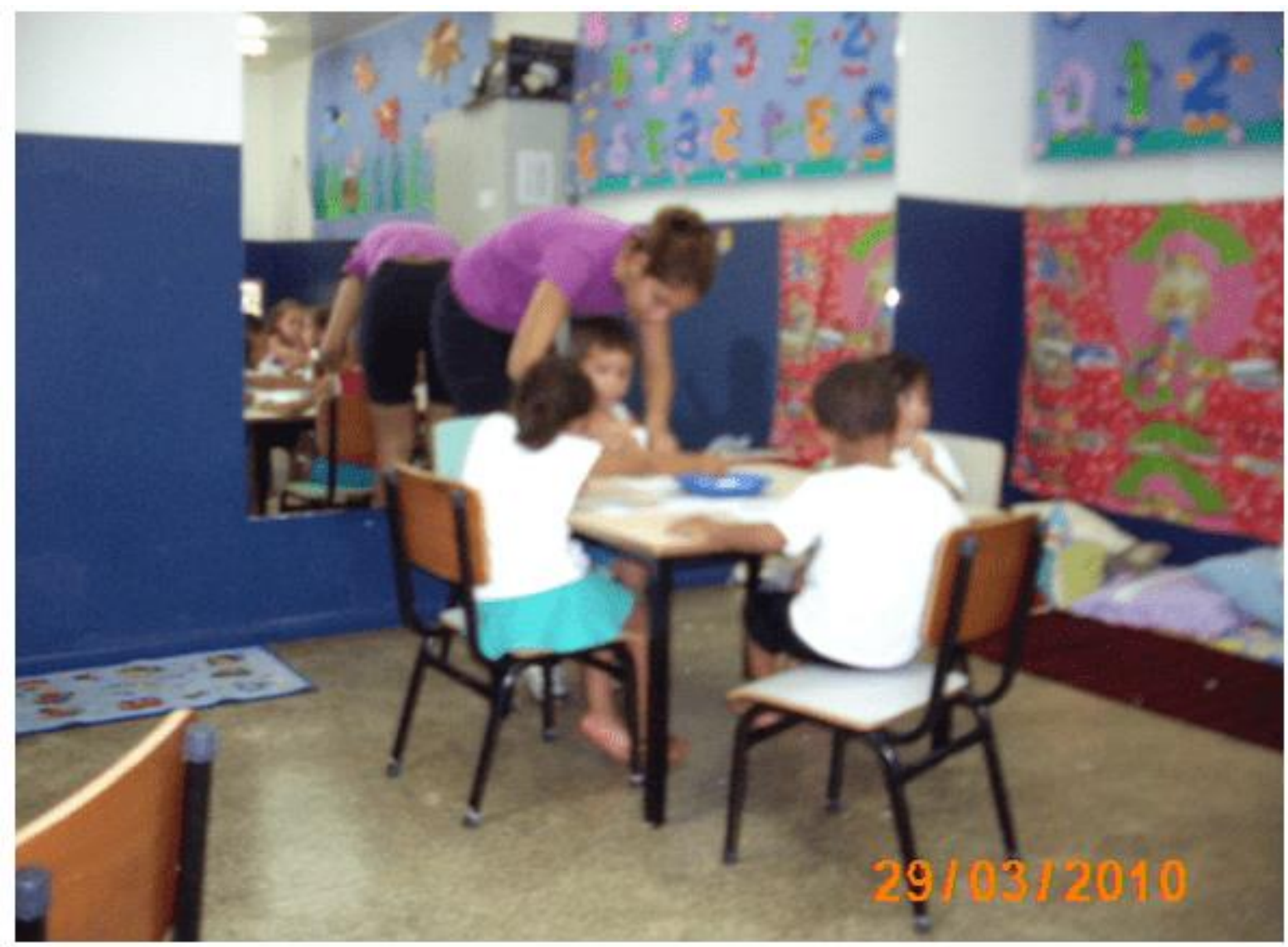

Fonte: Arquivo pessoal

RC: 61320

Disponível em: https://www.nucleodoconhecimento.com.br/educacao/estagio 


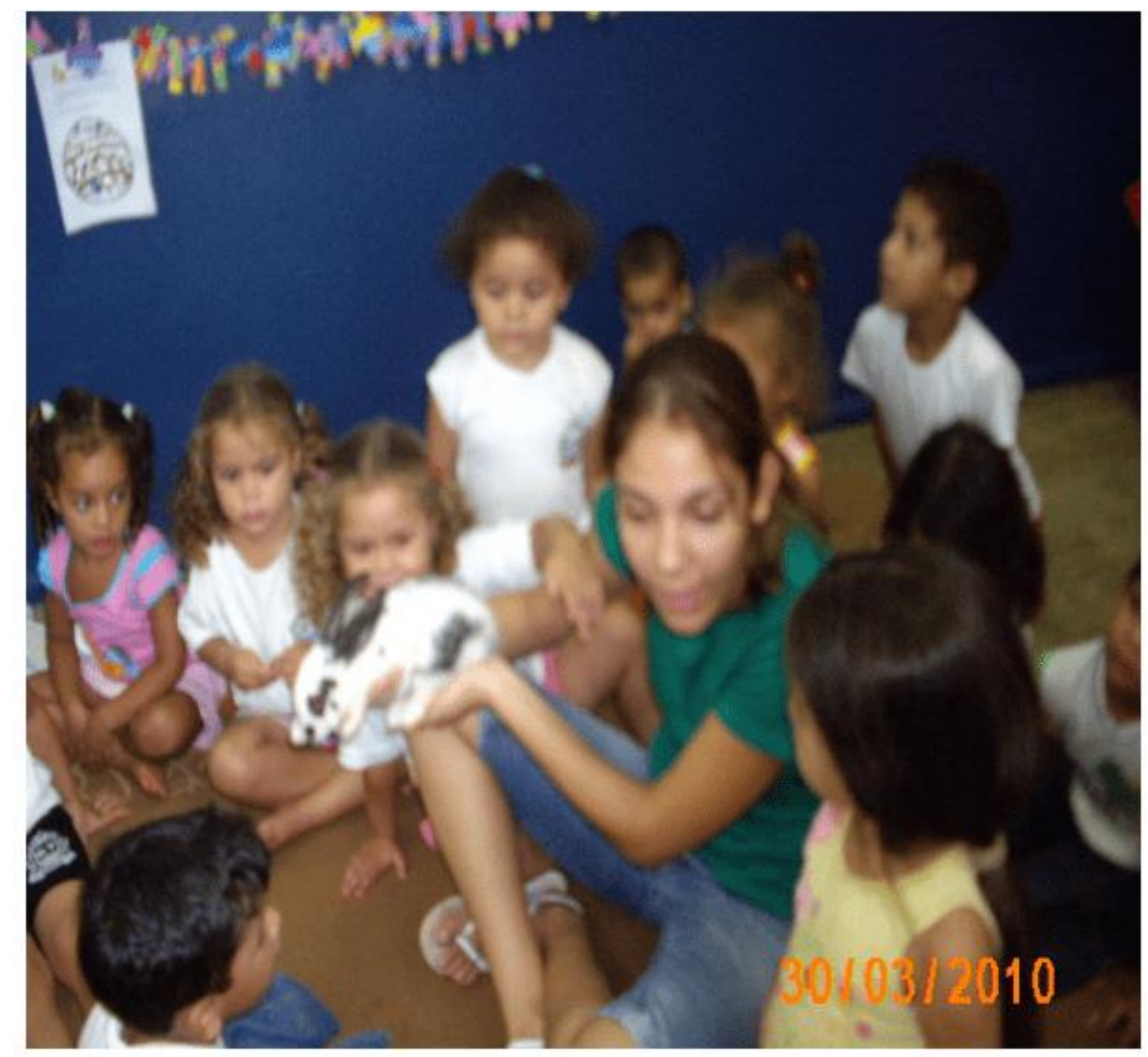

Fonte: Arquivo pessoal

RC: 61320

Disponível em: https://www.nucleodoconhecimento.com.br/educacao/estagio 


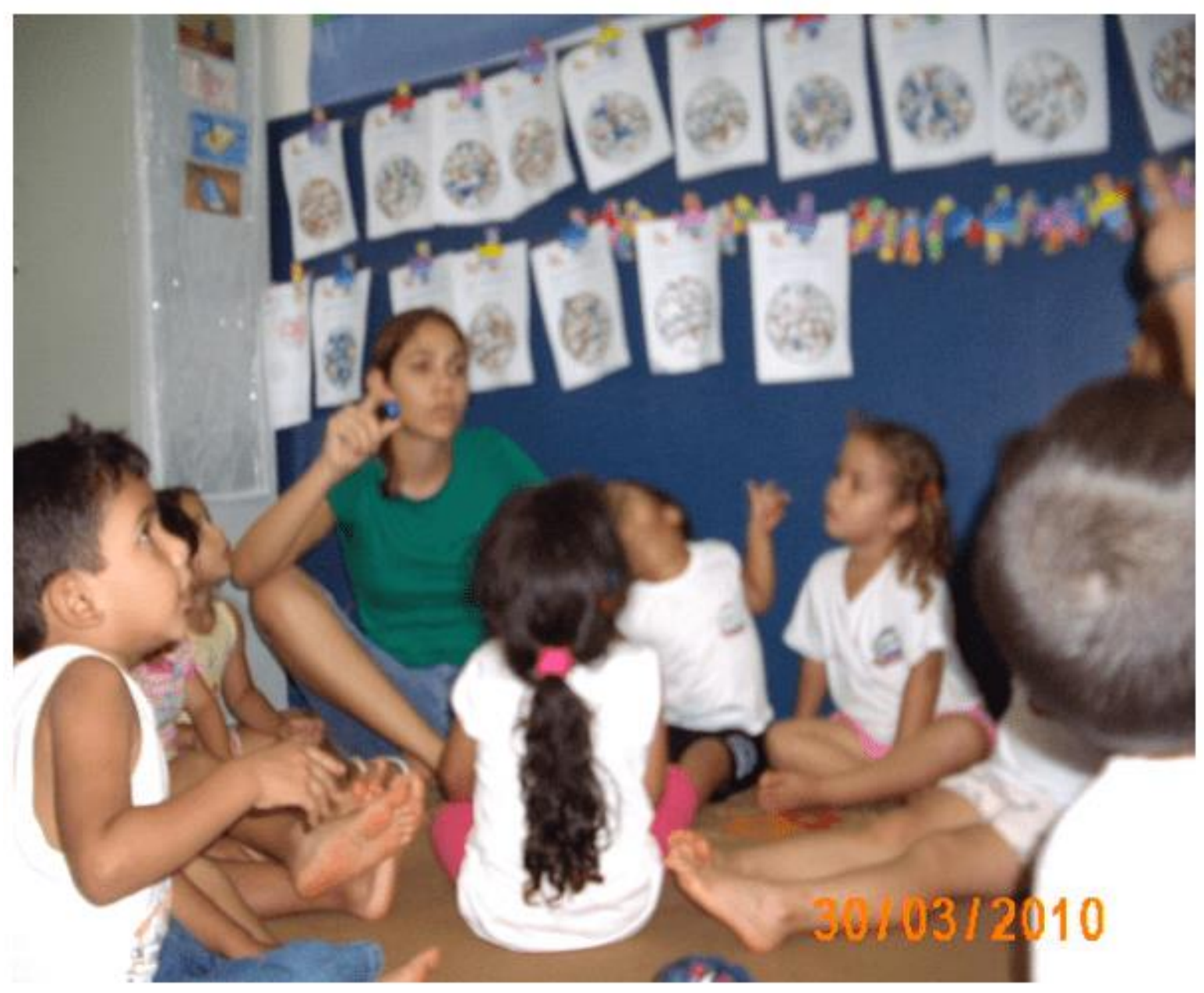

Fonte: Arquivo pessoal

RC: 61320

Disponível em: https://www.nucleodoconhecimento.com.br/educacao/estagio 


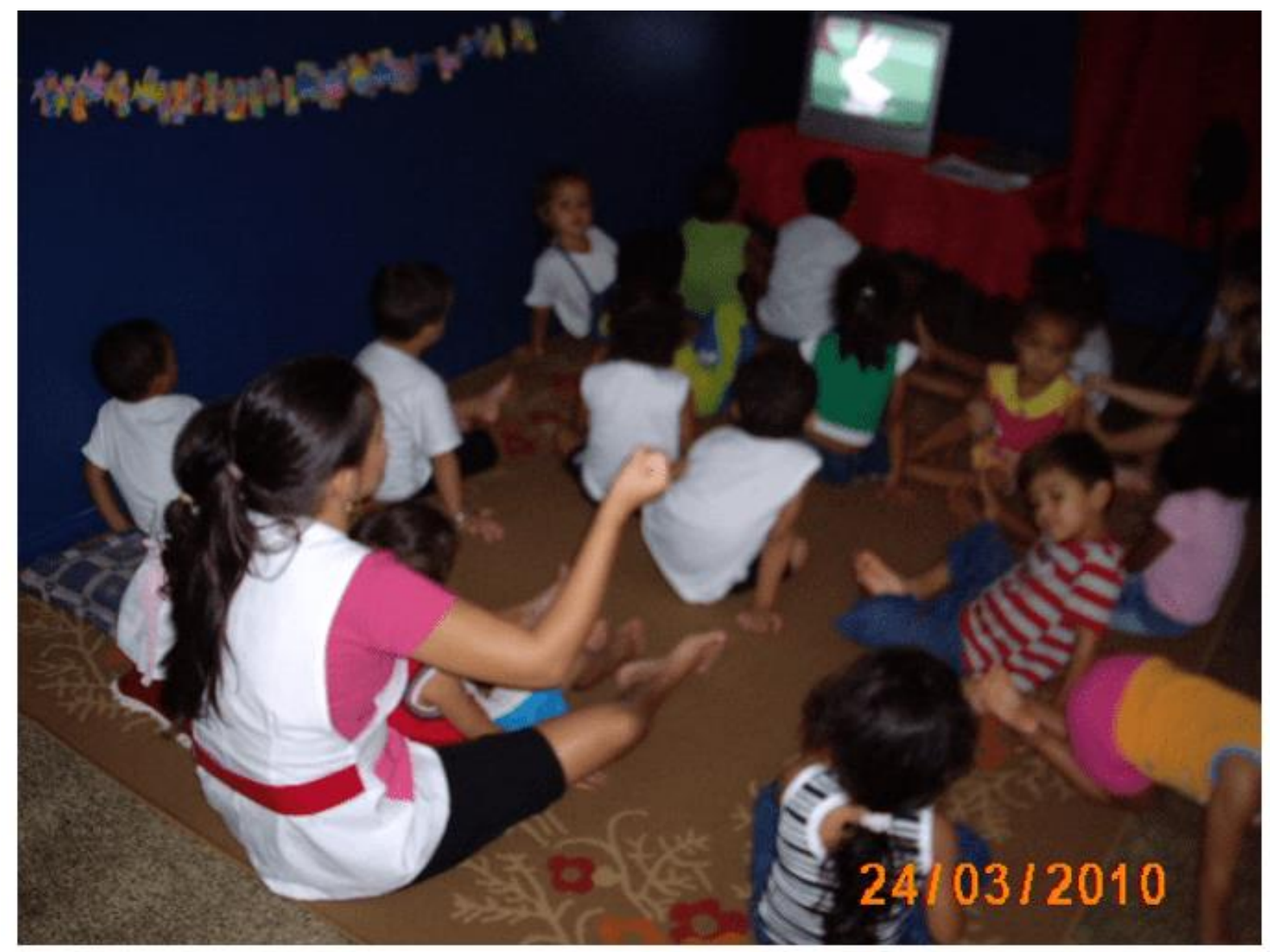

Fonte: Arquivo pessoal

RC: 61320

Disponível em: https://www.nucleodoconhecimento.com.br/educacao/estagio 


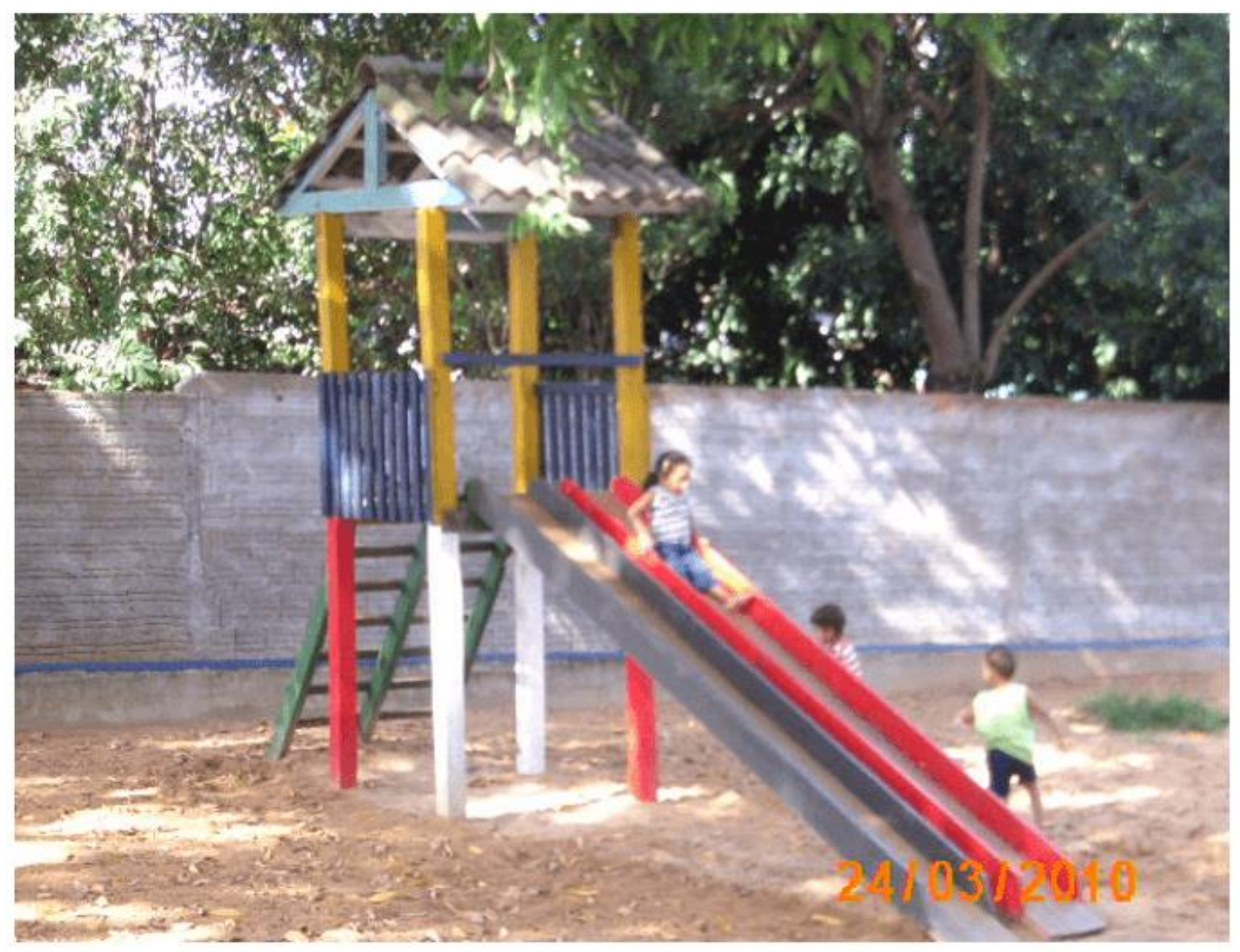

Fonte: Arquivo pessoal

Enviado: Outubro, 2020.

Aprovado: Outubro, 2020.

RC: 61320

Disponível em: https://www.nucleodoconhecimento.com.br/educacao/estagio 